\title{
THE EFFECT OF MONEY ETHICS ON ETHICAL ATTITUTES WITH RELIGIOSITY AS THE MODERATING VARIABLE
}

\author{
Fitri Ella Fauziah \\ Universitas Islam Nahdlatul Ulama' Jepara \\ Email: fitriella@unisnu.ac.id \\ Murharsito \\ Universitas Islam Nahdlatul Ulama' Jepara \\ Email: murharsito@unisnu.ac.id
}

Received: November 2018; Accepted: January 2019; Available online: January 2019

\begin{abstract}
This study aims to examine the influence of money ethics on ethical attitudes and to examine the influence of religiosity in moderating the relationship between money ethics and ethical attitudes. The population used in this study were all accounting students at Nahdlatul Ulama Islamic University in Jepara. The research sample was taken by purposive sampling method, 87 students elected as the research sample. The analysis technique used in the study is a residual test. This study used primary data by distributing questionnaires to students of the accounting department of the Islamic University of Nahdlatul Ulama 'Jepara. The results of the study showed that money ethics has no effect on ethical attitudes and religiosity cannot moderate the relationship between money ethics and ethical attitudes. The implication of this research is that ethics education is still needed in University, so that they have an understanding related to it.
\end{abstract}

Keywords: money ethics, ethics behavior, religiosity.

\begin{abstract}
Abstrak
Penelitian ini bertujuan untuk menguji pengaruh money ethics terhadap sikap etis serta menguji pengaruh religiosity dalam memoderasi hubungan antara money ethics terhadap sikap etis. Populasi yang digunakan penelitian ini adalah seluruh mahasiswa akuntansi di Universitas Islam Nahdlatul Ulama Jepara. Pengambilan sampel penelitian dilakukan dengan menggunakan metode purposive sampling, diperoleh 87 mahasiswa sebagai sampel penelitian. Teknik analisis yang digunakan dalam penelitian adalah uji residual. Penelitian ini menggunakan data primer yang dilakukan dengan menyebar kuesioner kepada mahasiswa jurusan akuntansi Universitas Islam Nahdlatul Ulama' Jepara. Hasil penelitian menunjukkan bahwa money ethics tidak berpengaruh terhadap sikap etis dan religiosity tidak dapat memoderasi hubungan antara money ethics dengan sikap etis. Implikasi penelitian ini bahwa pendidikan etika masih diperlukan di Universitas, sehingga mereka memiliki pemahaman yang terkait hal tersebut.
\end{abstract}

Kata Kunci: money ethics, sikap etis, religiosity.

How to Cite: Fauziah, F. E., \& Murharsito. (2019). The Effect of Money Ethics on Ethical Attitutes with Religiosity as the Moderating Variable. Media Ekonomi dan Manajemen, 34(1), 70-84. 


\section{INTRODUCTION}

Ethical attitudes are needed in various aspects of life, in society and also in business. Every individual in various fields of the profession is expected to promote ethical attitudes. Even for those who work as accountants can carry out their duties and obligations well and still maintain public trust by providing the right information. Cases which are related to ethics are tax avoidance by the tax officials themselves. Various efforts have been made by the government to avoid the occurrence of similar cases in the future by implementing various regulations. The Indonesian Accountants Association (IAI) has a code of ethics that must be possessed by accountant namely professional responsibility, public interest, integrity, objectivity, competence and professional prudence, confidentiality, professional behavior and technical standards. A good environment can foster person's sensitivity to all issues related to ethics, for example in the accounting education environment. Some studies that examine the use of ethics in accounting education, including those carried out by Armstrong et al. (2003), Bampton and Maclagan (2005), O'Leary (2009).

Based on O'Leary (2009), teaching of ethics has a positive effect on ethical attitudes of accounting students. Students' ethical attitudes can encourage them to behave ethically and not deviate. A dilemma in business ethics will occur when the duties and responsibilities received are not consistent with different groups of individuals (Finn et al. 1988, in Burks and Sellani, 2008). Supported by Hickman (2013) which states that students are expected to get professional responsibilities and this is needed when facing ethical dilemmas. Thus, ethical attitude is needed in the world of work or business. Some studies that examine the relationship between money ethics have been carried out by Lau et al. (2013) and Yesi (2014). Lau et al. (2013) and Yesi (2014) attempted to examine the relationship between money ethics and tax evasion with religiosity as a moderating variable. The results of their study stated that money ethics has a positive effect on tax avoidance, intrinsic religiosity can moderate the relationship between money ethics and tax avoidance while extrinsic religions provide the opposite results. Lau, Teck Chai (2010) examined money ethics and religiosity that are associated with socially responsible consumption. His research stated that religiosity has a significant influence on responsible consumption, while money ethics did not have a significant influence on responsible consumption.

Tang has conducted several studies related to money ethics or love money. In 2002, Tang stated that money ethics have a significant effect on unethical behavior. It was also said that individuals who have money ethics behavior, namely high love of money tend to behave unethically and sensitively compared to individuals who have low money ethics behavior. Tang and Liu (2012) conducted a study with the aim to find out how the influence of love of money on a person's tendency to conduct unethical behavior with integrity and character (ASPIRE) as a moderating variable. The research results stated that there is a significant interaction effect between love of money and character (ASPIRE) on unethical behavior. Wong (2007) revealed that there are differences in ethical attitudes in business over people who believe in Christianity at various levels of religiosity. It was also revealed that in the same belief group there are differences in love of money which resulted in differences in ethical behavior. However, just few studies that have examined the religiosity of the relationship between money ethics and ethical attitudes. This study attempts to add the variable religiosity as a moderating variable with the presumption that religiosity. As said by Hickman (2013), religiosity is an important thing to improve morals that are very necessary for individuals and professions. 
The allegation supports the results of his research which states that individuals with high levels of religiosity can improve the ethical attitude of accounting students. Thus this study adds religiosity as a moderating variable with the notion that religiosity can weaken or strengthen the relationship between money ethics and ethical attitudes.

\section{Research Problems}

Ethical attitude is very necessary for everyone who is involved in the community as well as in the professional environment. Maryani and Ludigdo (2001) interpreted ethics as the norm that regulates human behavior regarding things that need to be done or those that are not in the community or profession. Students especially in accounting will experience a dilemma related to the accounting profession. The accountant profession requires individuals to have big responsibilities. Money ethics behavior can play a role in determining whether a person can behave ethically or not. Tang (1999) stated that money ethics is the behavior of individuals who have a tendency to place money above everything. This is evidenced by the results of Tang's (2001) study which stated that money ethics has a significant influence on ethical attitudes. However, this study attempts to add the variable religiosity as a moderating variable which is thought to be able to bridge the relationship between the variable money ethics and ethical attitudes. Religiosity can be said as a belief in the Creator to carry out things that are in accordance with His teachings. Thus, it can be assumed that the individual variable religiosity as a moderating variable can strengthen or weaken the relationship between money ethics variables and ethical attitudes. Based on the formulation of the problem above, the research questions revealed in this study are : (1). Does money ethics affect ethical attitudes? (2). Does religiousity affect the relationship between money ethics and ethical attitudes?

\section{Research Purposes}

Based on the research questions, the objectives of this study are: (1) to examine the influence of money ethics on ethical attitudes, (2) to examine the influence of religiosity in moderating the relationship between money ethics and ethical attitudes.

\section{LITERATURES REVIEW Money Ethics}

According to Wankhar and Diana (2018), money ethics is a difference in the perception of each individual to assess the importance of money in life. Thus, the importance of money in life is different from one individual to another. Money Ethics can also be interpreted as a love of money. Lau et al. (2013) stated that someone who has high money ethics considers that money is everything, and tends to behave less ethically than someone who has a low money ethics. It can be said that money ethics is a deviant behavior that can have an impact on job satisfaction and the performance of individuals and companies. Even revealed by Tang and Chiu (2003), the root of crime is the love of money, but money is not a source of crime.

\section{Religiosity}

Bloodgood et al. (2007) gave conclusions on some definitions of religiosity from several researchers, namely understanding, commitment and religious beliefs or principles whereas according to McDaniel and Burnett (1990) in Lau et al. (2013), religiosity is trust in God accompanied by commitment to follow the principles determined by God. Also added by Keller et al. (2007) which states that religion provides guidance in determining what is right and wrong, religion is also the basis of ethics because someone who is religious can point to God 
as a source of ethics. A person's confidence in the Creator can control unethical behavior. Religion can play a role in preventing deviant behavior, because religion is a source of ethics for behaving in the community. A person who has high religiosity can have strong self control, in connection with his religious beliefs that prohibit such actions. The role of religion in the prevention of deviant behavior was put forward by Sulistyo (2014), Burton et.al (2011). Grullon et al. (2009) also stated that regulations and religion could be used as a mechanism to replace supervision and control. Alport and Ross (1967) conducted a study of religiosity which divided it into two, namely intrinsic and extrinsic religiosity. Intrinsic religiosity is used as a person's orientation to achieve the final goal, while extrinsic religiosity uses religion as a guideline to achieve one's own goals.

\section{Ethical Behavior}

In general, ethics is related to how someone behaves towards other individuals. As for Maryani and Ludigdo (2001) giving the notion of ethics as a norm that regulates human behavior regarding things that need to be done or those that are not in community groups or professions. Ethics can be used as a reference to morals that are generally unwritten. However, in an organization ethical behavior is set forth in a rule referred to as a professional code of ethics. This is needed to maintain the profession's reputation in the community. The accounting profession must refer to the code of ethics established by the Indonesian Institute of Accountants (IAI) which emphasizes ethical principles for accountants in carrying out their profession. The principle of professional ethics in the IAI Code of Ethics is the basis of professional behavior. consists of eight principles, namely: professional responsibility, public interest, integrity, objectivity, competence and professional prudence, confidentiality, professional behavior and technical standards (Sukrisno, 2012).

\section{Hipothesis}

\section{Relationship between Money Ethics and Ethical Attitudes}

Money Ethics is an attitude of love for money, in other words someone thinks money is everything. Tang (2002) revealed that money ethics which is held by someone directly and significantly influences unethical behavior. Thus it can encourage someone to be willing to do everything that is not justified. As revealed by Lau et al. (2013) states that someone who has high money ethics considers that money is everything, and tends to behave less ethically than someone who has a low ethic of money. Tang and Chen (2008) conducted a study to examine the effects of love of money and unethical behavior on business and psychology faculty students. The results of his research state that business faculty students experience changes in concepts related to unethical behavior after knowing business ethics, and tend not to behave unethically. Thus individuals who like money can make these individuals behave unethically. The hypotheses expressed in this study are:

$\mathrm{H}_{1} \quad$ : Money Ethics has a negative effect on ethical attitudes.

\section{Relationship between Money Ethics and Ethical Attitudes Moderated by Reli- giosity}

Money ethics behavior can play a role in determining whether a person can behave ethically or not. As stated by Tang (1999) that money ethics is a person's tendency to put money above everything and is proven by the results of his research in 2001 which stated that money ethics had a significant influence on ethical attitudes.

The influence of love of money (money ethics) on ethical attitudes can be moderated by religiosity. Religiosity is a belief in the God to carry out things that 
are principle and in accordance with His teachings. According to Wankhar and Diana (2018), ethical behavior or not someone is indirectly based on the beliefs of each individual, in other words a person's commitment based on religion (religiosity) will affect his behavior. Wong (2007) conducted a research on Christian faith communities. The results of his research state that there are differences in ethical attitudes in business at various levels of religiosity. Thus, it can be assumed that the individual variable religiosity as a moderating variable can strengthen or weaken the relationship between money ethics variables and ethical attitudes. The hypotheses expressed in this study are:

$\mathrm{H}_{2}$ : Religiosity can moderate the relationship between money ethics and ethical attitudes.

\section{Research Framework}

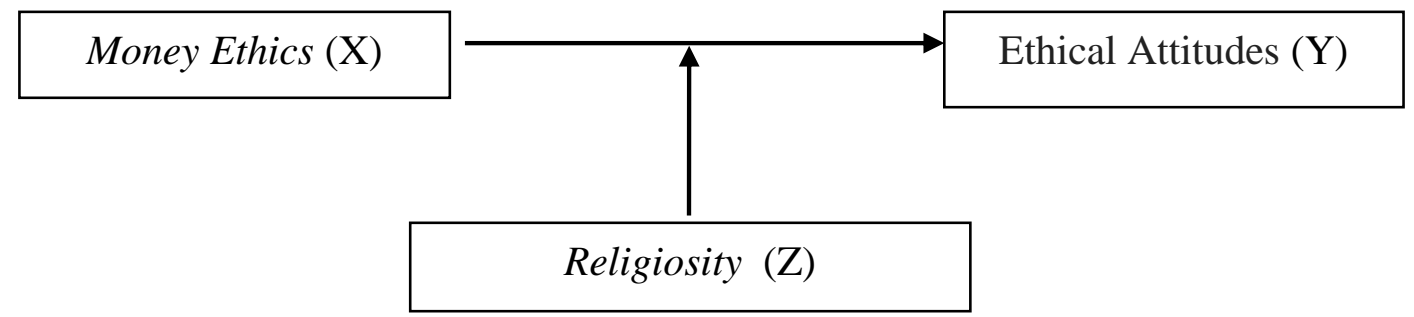

Figure 1.Research Framework

Ethical attitude is very necessary in the community, business and profession. Students, especially in the field of accounting, will experience a dilemma related to the accounting profession that requires great responsibility. Money ethics behavior can play a pivotal role in determining whether a person can behave ethically or not. Tang (1999) stated that money ethics is the behavior of individuals who have a tendency to place money above everything else, so that there is a tendency for individuals with high levels of money ethics tend not to behave ethically. Religiosity can be said as a belief in the Creator to carry out things that are in accordance with His teachings. Thus, it can be assumed that the individual variable religiosity as a moderating variable can strengthen or weaken the relationship between money ethics variables and ethical attitudes

\section{RESEARCH METHOD}

\section{Population and sample}

The population used in this study were all accounting students at Nahdlatul Ulama Islamic University in Jepara. The research sampling technique using purposive sampling method with the criteria: (a) final semester accounting students, (b) accounting students who have completed auditing courses. Based on these criteria, a sample that can be used in the study is 87 .

\section{Research Variable and Variable Operational Definition Dependent Variable}

The dependent variable used in this study is Ethical Attitude. Tikolla et al (2006) stated that ethical attitudes are attitudes that are in accordance with the social norms of society that are generally accepted. The measurement of ethical 
attitudes in this study uses professional ethics measurements established by the Indonesian Institute of Accountants (IAI) which include:

- Dimensions of professional responsibility with professional attitude indicators, comply with legal regulations and are guided by a code of ethics.

- Dimensions of public interest with public service indicators, respecting public interests and commitment and professionals.

- Integrity dimension with indicators of public trust, not accepting fraud and being honest and fair

- Objectivity dimensions with indicators of being fair and impartial, promotion, free from personal interests.

- Competency dimensions and professional prudence with indicators of educational competence, professional knowledge, professional services, prudence and perseverance.

- Dimensions of confidentiality with indicators respecting other people's secrets, commitment and professional services.

- Dimensions of professional behavior with indicators of consistency, public interest and professional behavior.

- Dimensions of technical standards with indicators of technical standards, conformity with expertise, prudence and standards of professional services.

\section{Independent Variable}

Variabel The independent variable in this study is Money Ethics. Tang (1999) measures money ethics as someone's love for money that exceeds everything. This study measures the variable money ethics adopted from Tang (2002) in Yesi (2016).

\section{Moderating Variable}

The moderating variable used in this study is religiosity. Relogiosity is a belief or belief that an individual has. The indicator used to measure the religiosity variable adopted from Alport and Ross (1967) in Yesi (2016).

\section{Data Collection Techniques}

The research data was collected through distributing questionnaires to students of Islamic University of Nahdlatul Ulama (UNISNU) Jepara of accounting program.

\section{Data Analysis}

Analysis of this research data include: descriptive statistical analysis, validity and reliability test, classic assumption, residual test.

a. Descriptive statistical analysis

Descriptive statistical analysis is used to determine the statistical value of the variables in the study, through mean, minimum, maximum and standard deviation values.

b. Validity and Reliability Test

This test is conducted to test whether the questions used in this study are valid and reliable.

c. Classic Assumption Test

Classic assumption test is used to find out whether the data used in this study can achieve good conditions so that it can be tested using Ordinary Least Square (OLS). This classic assumption test includes: normality, multicollinearity, autocorrelation and heteroscedasticity.

d. Hypothesis Testing

Ghozali (2006) states that residual analysis is done to test the effect of deviation of a model that focuses on lack of fit resulting from the deviation of linear relationships between independent variables. Lack of fit is indicated by the residual value in regression. The conclusions that can be drawn from the results of the residual test are if the value of the 
parameter coefficient is negative and significant, the variable Religiosity can be said as a moderating variable. The residual testing step is described as follows:

Religiosity $=\mathrm{a}+\mathrm{b} 1$ Money Ethics $+\mathrm{e} \ldots$ 1)

$\mathrm{e}=\mathrm{a}+\mathrm{b} 1$ Ethical Attitude

\section{RESULTS AND DISCUSSION}

\section{Descriptive Statistics Results}

Descriptive statistical analysis provides an overview of the data seen through the minimum, maximum, average and standard deviations of each research variable presented in the following Table 1.

\section{Validity and Reliability Test}

Based on Table 1, the value of Corrected Item-Total Correlation shows the value of the validity of question items, while the value of Cronbach's Alpha if Item Deleted shows the reliability value of the question item. Determining whether or not the question item is valid is done by comparing the values with $\mathrm{R}$ table. The $\mathrm{R}$ table in this study is df $=\mathrm{N}-2=77-2=$ 75 and the probability is 0.05 , so the value of the $\mathrm{R}$ table obtained is 0.2242 . Thus, there are 3 items that are invalid questions, namely $5,15,20$ so it is necessary to discard the three question items. The results of the validity and reliability test after removing the 3 item questions are as Table 3.

Table 3 shows that the value of Corrected Item-Total Correlation is greater than $\mathrm{R}$ table and the reliability value for all item questions is reliable because the value of Cronbach's Alpha if Deleted Item exceeds $60 \%$. So it was concluded that the items in the money ethics variable were valid and reliable.

Table 4 shows that the value of Corrected Item-Total Correlation is greater than $\mathrm{R}$ table which is 0.2242 and the reliability value for all item questions is reliable because the value of Cronbach's Alpha if Deleted Item exceeds $60 \%$. So it can be concluded that the item question variable religiosity is valid and reliable.

\section{Classis Assumption Test Result Normality}

The normality test is done to find out whether the residual value of a regression has a normal distribution or cannot be analyzed graphically or statistically (Ghozali, 2006). The results of graphs and statistics are presented in figure 2 and table 5.

Based on the picture, it shows that the pattern on the histogram graph is normally distributed and normal probability plot images also show that the points spread around the diagonal line and the spread is close to the diagonal line. The results of statistical analysis are shown through statistical analysis using the Kolmogorov - Smirnov test as Table 6.

The Kolmogorov - Smirnov test results show a significance value of 0.331 or> 0.05 , so that it can be concluded that the residual data is normally distributed.

\section{Multicolinierity}

Multicolinearity test is intended to find out whether there is a correlation between independent variables in a regression model. A good regression model is that there is no correlation between independent variables. If the tolerance value shows a value of more than 0.10 and a VIF value of less than 10, then there is no correlation between the independent variables in the regression model and it is concluded that there is no multicollinearity (Ghozali, 2006).

Based on the Table 7, it is shown that the tolerance value is 0.795 (more than 0.10 ) and the VIF value is 1,258 (less than $10)$, so it is concluded that multicollinearity does not occur.

\section{Autokorelation}

The autocorrelation test used in this study is Run Test. This test is used to determine whether residual data occurs randomly or not (systematically). 
The output of the Run Test in Table 8 shows that the test value is 0.09264 with a probability of 0.302 not significant at 0.05 , which means that the null hypothesis is accepted. Thus it can be concluded that the residual is random or there is no autocorrelation between residual values.

\section{Heteroskedastisity}

Heteroscedasticity test aims to determine whether in the regression model variance from residual inequality occurs one observation to another observation (Ghozali, 2006). The picture in Figure 3 presented shows that the data is spread both above and below 0 on the $\mathrm{Y}$ axis, so it can be concluded that there is no heteroscedasticity in this research model.

\section{Effects of Money Ethics on Ethical Attitudes}

The SPSS output in the Table 9 shows that the money ethics variable and ethical attitude have a negative influence with a value of 0.007 . Thus, it can be concluded that the one hypothesis which states money ethics has a negative effect on ethical attitudes is supported and rejects the null hypothesis. However, the results of this study provide a significance value of 0.950 or more than 0.05 , which means that money ethics has no significant effect on ethical attitudes. Money Ethics is a bad attitude that considers money to be everything. Students who have knowledge of money ethics have a tendency not to make these deviations. Thus, students with low money ethics will improve their ethical attitude.

The results of this study are not in line with the results of research conducted by Burks and Sellani (2008) which states that religiosity has an influence on student morale. The arguments that can explain the results of this study are based on the results of descriptive statistical analysis. Respondents who answered the questionnaire on the Likert scale 1.2 and 3 were $50.88 \%$, while the Likert scale 4 and 5 were $49.93 \%$. Likert 1,2 and 3 scales show the respondent's answers strongly disagree, disagree and neutral, while 4 and
5 show the answers agree and strongly agree. Thus the proportion of students who approve or consider money is everything with students who are hesitant and who don't approve money is almost the same. Students still need education about ethics so that they have an understanding related to it. Also said by Hegarty and Sims (1978, 1979) in Lau et al. (2017) that personal factors also contribute to the formation of ethical behavior.

The Effect of Religiosity in Moderating the Relationship between Money Ethics and Ethical Attitudes

Based on the Table 10, the residual test model can be formulated in the following equation:

$|\mathrm{e}|=\mathrm{a}+\mathrm{b}_{1}$ Ethical Attitude

$|\mathrm{e}|=8.599-0.037$ Ethical Attitude....... 4)

Table 10 shows that the ethical attitude variable has a negative parameter coefficient that is equal to -0.037 and has a significance level of 0.601 , where the value is greater than 0.05 . According to Ghozali (2006) a variable is called a moderating variable if it has a negative parameter coefficient and has a significant effect. The religiosity variable cannot be said as a moderating variable because it has a significance level that exceeds 0.05 , so it can be concluded that the second hypothesis is not supported. In other words, religiosity cannot influence the relationship between money ethics and ethical attitudes.

The results of this study are consistent with the results of a study conducted by Lau et al. (2017) and Yesi (2014) who conducted a study by testing the effect of money ethics on the tax evasion with religiosity as a moderating variable. Tax Evasion is a form of unethical attitude. The results of his research state that individuals with extrinsic religiosity cannot moderate the relationship between money ethics and ethical attitudes. Some studies that examine the effect of religiosity and ethical attitudes have been carried out, including McDonald and Pak (1997) who conducted 
the study and gave results that religiosity does not have a significant relationship to ethical attitudes. Hegarty and Sims (1978, 1979) in Lau et al. (2017) which examines the influence of personal factors on ethical attitudes and gives results that religiosity has no significant effect. Similarly, Kidwell et al. (1987) which states that church attendance as a proxy for variable religiosity does not affect ethical attitudes.

Based on the testing of the influence of money ethics and ethical attitudes, the results bring that the money ethics variable has no effect on ethical attitudes. Similarly, the addition of the variable religiosity as a moderating variable gives the result that religiosity is not able to moderate the relationship between money ethics and ethical attitudes. Even though respondents' answers related to religiosity showed that the Likert scale 4 and 5 was $66.84 \%$, it still could not moderate the relationship between religiosity and ethical attitude. This is probably still motivated by personal factors as revealed by Hegarty and Sims $(1978,1979)$ in Lau et al. (2017) and lack of money ethics education for respondents.

Table 1. Descriptive Statistics

\begin{tabular}{lrrrrrrr}
\hline & N & Range & Min & Max & \multicolumn{2}{c}{ Mean } & Std. Deviation \\
& Statistic & Statistic & Statistic & Statistic & Statistic & Std. Error & Statistic \\
\hline Ethical Attitude & 77 & 50.00 & 53.00 & 103.00 & 82.9870 & .99064 & 8.69285 \\
Money Ethics & 77 & 40.00 & 30.00 & 70.00 & 46.4805 & .96780 & 8.49243 \\
Religiosity & 77 & 44.00 & 56.00 & 100.00 & 75.1299 & .98230 & 8.61967 \\
Valid N (listwise) & 77 & & & & & & \\
\hline
\end{tabular}

Source: Secondary Data processed, 2018

Table 2. Validity and Reliability Test Result on Ethical Attitude Variable Item-Total Statistics

\begin{tabular}{lcrrrrl}
\hline & $\begin{array}{c}\text { Scale Mean } \\
\text { if Item } \\
\text { Deleted }\end{array}$ & $\begin{array}{c}\text { Scale } \\
\text { Variance if } \\
\text { Item Deleted }\end{array}$ & $\begin{array}{c}\text { Corrected } \\
\text { Item-Total } \\
\text { Correlation }\end{array}$ & $\begin{array}{c}\text { Cronbach's } \\
\text { Alpha if Item } \\
\text { Deleted }\end{array}$ & Valid & Reliable \\
\hline SE1 & 176.2500 & 492.238 & .676 & .732 & Valid & Reliable \\
SE2 & 175.9881 & 498.301 & .557 & .735 & Valid & Reliable \\
SE3 & 176.0119 & 494.735 & .562 & .733 & Valid & Reliable \\
SE4 & 176.2976 & 492.212 & .651 & .732 & Valid & Reliable \\
SE5 & 177.4167 & 506.945 & .200 & .741 & UnValid & Reliable \\
SE6 & 176.5952 & 506.678 & .237 & .741 & Valid & Reliable \\
SE7 & 176.2738 & 493.719 & .609 & .733 & Valid & Reliable \\
SE8 & 177.0476 & 494.142 & .507 & .733 & Valid & Reliable \\
SE9 & 176.6190 & 502.311 & .381 & .738 & Valid & Reliable \\
SE10 & 176.3571 & 491.991 & .654 & .731 & Valid & Reliable \\
SE11 & 177.2857 & 497.556 & .378 & .736 & Valid & Reliable \\
SE12 & 176.6786 & 500.703 & .438 & .737 & Valid & Reliable \\
SE13 & 176.6071 & 493.446 & .609 & .732 & Valid & Reliable \\
SE14 & 176.3810 & 487.106 & .765 & .728 & Valid & Reliable \\
SE15 & 177.8214 & 504.414 & .066 & .740 & UnValid & Reliable \\
SE16 & 176.2262 & 497.334 & .501 & .735 & Valid & Reliable \\
SE17 & 176.2024 & 490.453 & .747 & .730 & Valid & Reliable \\
SE18 & 176.3571 & 492.208 & .636 & .732 & Valid & Reliable \\
SE19 & 176.3214 & 494.630 & .620 & .733 & Valid & Reliable \\
SE20 & 176.9881 & 512.735 & .082 & .744 & UnValid & Reliable \\
SE21 & 176.2500 & 487.443 & .627 & .729 & Valid & Reliable \\
SE22 & 176.1667 & 489.900 & .638 & .730 & Valid & Reliable \\
SE23 & 176.2738 & 493.334 & .598 & .732 & Valid & Reliable \\
SE24 & 176.2976 & 491.224 & .604 & .731 & Valid & Reliable \\
\hline Source: & & & & &
\end{tabular}

Source: Secondary Data processed, 2018 
Table 3.Validity and Reliability Test Result on Ethical Attitude Variable

\begin{tabular}{lrrrrrl}
\multicolumn{7}{c}{ Item-Total Statistics } \\
& $\begin{array}{c}\text { Scale Mean } \\
\text { if Item } \\
\text { Deleted }\end{array}$ & $\begin{array}{c}\text { Scale } \\
\text { Variance if } \\
\text { Item Deleted }\end{array}$ & $\begin{array}{c}\text { Corrected } \\
\text { Item-Total } \\
\text { Correlation }\end{array}$ & $\begin{array}{c}\text { Cronbach's } \\
\text { Alpha if Item } \\
\text { Deleted }\end{array}$ & Valid & Reliable \\
\hline SE1 & 78.88 & 68.184 & .579 & .872 & Valid & Reliable \\
SE2 & 78.64 & 69.682 & .491 & .875 & Valid & Reliable \\
SE3 & 78.64 & 69.392 & .421 & .877 & Valid & Reliable \\
SE4 & 78.95 & 66.813 & .619 & .870 & Valid & Reliable \\
SE6 & 79.26 & 70.826 & .266 & .883 & Valid & Reliable \\
SE7 & 78.91 & 68.242 & .555 & .873 & Valid & Reliable \\
SE8 & 79.69 & 67.586 & .472 & .876 & Valid & Reliable \\
SE9 & 79.26 & 71.458 & .295 & .880 & Valid & Reliable \\
SE10 & 79.01 & 67.197 & .609 & .871 & Valid & Reliable \\
SE11 & 79.95 & 69.603 & .261 & .886 & Valid & Reliable \\
SE12 & 79.34 & 69.911 & .391 & .878 & Valid & Reliable \\
SE13 & 79.25 & 65.899 & .694 & .868 & Valid & Reliable \\
SE14 & 79.01 & 66.618 & .712 & .868 & Valid & Reliable \\
SE16 & 78.83 & 68.116 & .613 & .871 & Valid & Reliable \\
SE17 & 78.83 & 68.642 & .626 & .871 & Valid & Reliable \\
SE18 & 79.00 & 69.184 & .493 & .875 & Valid & Reliable \\
SE19 & 78.95 & 70.787 & .408 & .877 & Valid & Reliable \\
SE21 & 78.83 & 68.668 & .463 & .876 & Valid & Reliable \\
SE22 & 78.73 & 71.254 & .413 & .877 & Valid & Reliable \\
SE23 & 78.88 & 69.841 & .448 & .876 & Valid & Reliable \\
SE24 & 78.91 & 70.057 & .440 & .876 & Valid & Reliable \\
\hline
\end{tabular}

Source: Secondary Data processed, 2018

The table shows that the value of the Corrected Item-Total Correlation is greater than the $\mathrm{R}$ table which is 0.2242 . The reliability values for all question items are reliable because their values exceed $60 \%$.

Table 4. Validity and Reliability Test Result on Money Ethics Variable

Item-Total Statistics

\begin{tabular}{lrrrrl}
\hline & $\begin{array}{c}\text { Scale Mean if } \\
\text { Item Deleted }\end{array}$ & $\begin{array}{c}\text { Scale Variance } \\
\text { if Item Deleted }\end{array}$ & $\begin{array}{c}\text { Corrected Item- } \\
\text { Total Correlation }\end{array}$ & $\begin{array}{c}\text { Cronbach's Alpha } \\
\text { if Item Deleted }\end{array}$ & Valid dan Reliable \\
\hline ME1 & 46.48 & 72.121 & .318 & .881 & Valid dan Reliable \\
ME2 & 46.45 & 73.356 & .274 & .882 & Valid dan Reliable \\
ME3 & 46.69 & 71.559 & .363 & .880 & Valid dan Reliable \\
ME4 & 47.05 & 69.471 & .430 & .878 & Valid dan Reliable \\
ME5 & 47.65 & 71.520 & .307 & .883 & Valid dan Reliable \\
ME6 & 47.56 & 65.381 & .626 & .869 & Valid dan Reliable \\
ME7 & 47.25 & 63.373 & .726 & .863 & Valid dan Reliable \\
ME8 & 47.68 & 63.170 & .763 & .861 & Valid dan Reliable \\
ME9 & 47.68 & 63.354 & .772 & .861 & Valid dan Reliable \\
ME10 & 47.26 & 65.511 & .670 & .867 & Valid dan Reliable \\
ME11 & 47.74 & 64.853 & .670 & .866 & Valid dan Reliable \\
ME12 & 47.52 & 65.332 & .670 & .867 & Valid dan Reliable \\
ME13 & 47.10 & 64.621 & .685 & .866 & Valid dan Reliable \\
ME14 & 46.43 & 72.906 & .322 & .881 & Valid dan Reliable \\
ME15 & 46.38 & 72.580 & .289 & .882 & Valid dan Reliable \\
\hline
\end{tabular}

Source: Secondary Data processed, 2018 
Table 5. Validity and Reliability Test Result on Religiosity Variable

Item-Total Statistics

\begin{tabular}{lrrrrl}
\hline & $\begin{array}{c}\text { Scale Mean if } \\
\text { Item Deleted }\end{array}$ & $\begin{array}{c}\text { Scale Variance } \\
\text { if Item Deleted }\end{array}$ & $\begin{array}{c}\text { Corrected Item- } \\
\text { Total Correlation }\end{array}$ & $\begin{array}{c}\text { Cronbach's Alpha } \\
\text { if Item Deleted }\end{array}$ & Valid dan Reliable \\
\hline R1 & 71.58 & 69.536 & .307 & .851 & Valid dan Reliable \\
R2 & 71.22 & 70.122 & .251 & .853 & Valid dan Reliable \\
R3 & 71.01 & 69.645 & .407 & .847 & Valid dan Reliable \\
R4 & 70.96 & 68.854 & .460 & .846 & Valid dan Reliable \\
R5 & 70.83 & 67.984 & .469 & .845 & Valid dan Reliable \\
R6 & 71.61 & 66.294 & .575 & .840 & Valid dan Reliable \\
R7 & 71.26 & 68.063 & .486 & .844 & Valid dan Reliable \\
R8 & 70.97 & 67.605 & .516 & .843 & Valid dan Reliable \\
R9 & 71.99 & 64.829 & .496 & .843 & Valid dan Reliable \\
R10 & 71.86 & 67.729 & .390 & .848 & Valid dan Reliable \\
R11 & 70.95 & 70.234 & .314 & .850 & Valid dan Reliable \\
R12 & 71.36 & 66.261 & .560 & .841 & Valid dan Reliable \\
R13 & 70.99 & 70.724 & .281 & .851 & Valid dan Reliable \\
R14 & 71.31 & 65.796 & .498 & .843 & Valid dan Reliable \\
R15 & 72.26 & 65.458 & .404 & .849 & Valid dan Reliable \\
R16 & 71.70 & 63.975 & .553 & .840 & Valid dan Reliable \\
R17 & 71.64 & 63.498 & .573 & .839 & Valid dan Reliable \\
R18 & 71.70 & 67.054 & .422 & .847 & Valid dan Reliable \\
R19 & 71.53 & 68.463 & .403 & .847 & Valid dan Reliable \\
R20 & 70.73 & 69.385 & .427 & .847 & Valid dan Reliable \\
\hline
\end{tabular}

Source: Secondary Data processed, 2018

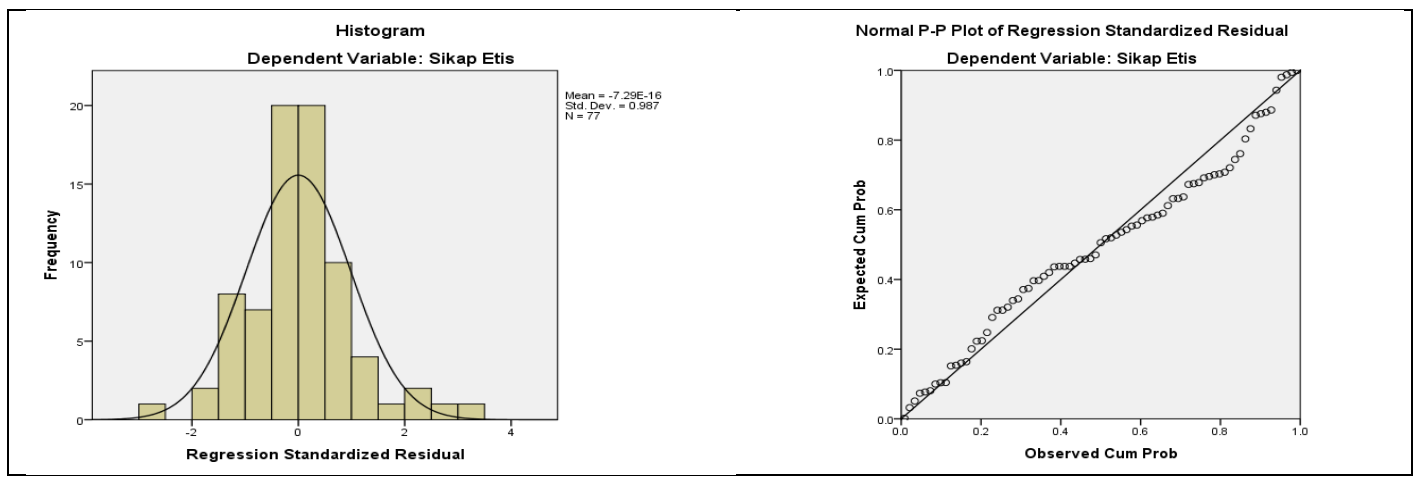

Figure 2.Histogram and Normal P-Plot of Regression Standardized Residual Source: Secondary Data processed, 2018 
Table 6. Kolmogorov Smirnov Test Result

One-Sample Kolmogorov-Smirnov Test

\begin{tabular}{llr}
\hline & & \multicolumn{2}{c}{ Unstandardized Residual } \\
\hline $\mathrm{N}$ & & 77 \\
Normal Parameters & Mean & $0 \mathrm{E}-7$ \\
& Std. Deviation & 6.57355415 \\
Most Extreme & Absolute & .108 \\
Differences & Positive & .108 \\
Kolmogorov-Smirnov Z & Negative & -.076 \\
Asymp. Sig. (2-tailed) & .947 \\
\hline
\end{tabular}

a. Test distribution is Normal.

b. Calculated from data.

Source: Secondary Data processed, 2018

Table 7. Multikolinieritas Test Result

Coefficients $^{\mathrm{a}}$

\begin{tabular}{|c|c|c|c|c|c|c|}
\hline \multirow{2}{*}{\multicolumn{2}{|c|}{ Model }} & \multicolumn{2}{|c|}{$\begin{array}{l}\text { Unstandardized } \\
\text { Coefficients }\end{array}$} & \multirow{2}{*}{$\begin{array}{c}\text { Standardized } \\
\text { Coefficients } \\
\text { Beta } \\
\end{array}$} & \multicolumn{2}{|c|}{$\begin{array}{c}\text { Collinearity } \\
\text { Statistics }\end{array}$} \\
\hline & & $\mathrm{B}$ & Std. Error & & Tolerance & VIF \\
\hline \multirow{3}{*}{1} & (Constant) & 43.541 & 6.830 & & & \\
\hline & $\begin{array}{l}\text { Money } \\
\text { Ethics }\end{array}$ & -.348 & .101 & -.340 & .795 & 1.258 \\
\hline & Religiosity & .740 & .099 & .734 & .795 & 1.258 \\
\hline
\end{tabular}

a. Dependent Variable: Ethical Attitude

Source: Secondary Data processed, 2018

Table 8.Autokorelasi Test Result

Runs Test

\begin{tabular}{lr}
\hline & Unstandardized Residual \\
\hline Test Value $^{\mathrm{a}}$ & .09264 \\
Cases $<$ Test Value & 38 \\
Cases $>=$ Test Value & 39 \\
Total Cases & 77 \\
Number of Runs & 35 \\
Z & -1.031 \\
Asymp. Sig. (2-tailed) & .302 \\
\hline
\end{tabular}

a. Median

Source: Secondary Data processed, 2018 


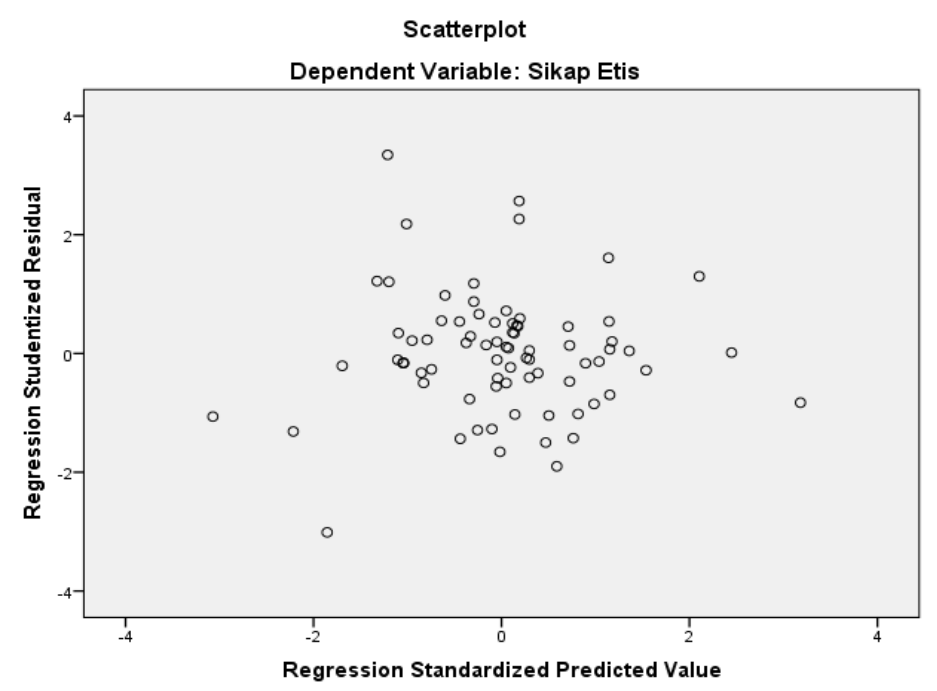

Figure 3. Heteroskedasticity Test Result

Source: Secondary Data processed, 2018

Table 9. Regression Result Money Ethics dan Ethical Attitude

Coefficients $^{\mathrm{a}}$

\begin{tabular}{llrrrrr}
\hline Model & & Unstandardized Coefficients & \multicolumn{1}{c}{$\begin{array}{c}\text { Standardized } \\
\text { Coefficients Beta }\end{array}$} & t & Sig. \\
& & B & Std. Error & & & \\
\hline \multirow{2}{*}{1} & (Constant) & 83.331 & 5.583 & & 14.925 & .000 \\
& Money Ethics & -.007 & .118 & -.007 & -.063 & .950 \\
\hline
\end{tabular}

a. Dependent Variable: Ethical Attitude

Source: Secondary Data processed, 2018

Table 10. Residual Test Result Religiosity Moderate Money Ethics and Ethical Attitude

Coefficients $^{\mathrm{a}}$

\begin{tabular}{|c|c|c|c|c|c|c|}
\hline \multirow{2}{*}{\multicolumn{2}{|c|}{ Model }} & \multicolumn{2}{|c|}{ Unstandardized Coefficients } & \multirow{2}{*}{$\begin{array}{l}\text { Standardized } \\
\text { Coefficients } \\
\text { Beta }\end{array}$} & \multirow[t]{2}{*}{$\mathrm{t}$} & \multirow[t]{2}{*}{ Sig. } \\
\hline & & B & Std. Error & & & \\
\hline \multirow{2}{*}{1} & (Constant) & 8.599 & 5.828 & & 1.476 & .144 \\
\hline & Ethical Attitude & -.037 & .070 & -.060 & -.525 & .601 \\
\hline
\end{tabular}

a. Dependent Variable: AbsRes_1

Source: Secondary Data processed, 2018

\section{CONCLUSION}

Based on the results and discussion, the conclusions that can be drawn in this study are: (1). Variable money ethics has no effect on ethical attitudes. The findings of this study provide evidence that an understanding of money ethics is very important. This is needed for a good personal formation which in the end can be a provision in the world of work. On the other hand, the sustainability of an organization also needs to pay attention to the psychological side of each individual in order to avoid things that are not desirable. (2) The variable religiosity cannot moderate the relationship between money ethics and ethical attitudes. Religiosity is a belief in God to carry out things that are principle and in accordance with His teachings. In theory, individuals with high 
religiosity can improve ethical attitudes. However, in this study the results show that religiosity cannot bridge the relationship between money ethics and ethical attitudes. This might be motivated by personal factors as revealed in the research of Hegarty and Sims $(1978,1979)$ in Lau et al. (2017). Besides that it is possible because of the lack of money ethics education of respondents, so moral education is needed to improve the students' perspective on money.

\section{RESEARCH RECOMMENDATIONS AND LIMITATIONS}

The advice that can be given in research is to provide understanding of money ethics to students. Thus it can provide a broader and more useful perspective for students at this time and when socializing with the community in the future. This study has several limitations, namely the sample used in this study is among students. Student perceptions related to money ethics are still very narrow, so that further research can expand the sample of research such as financial organizations or in governments that are at risk of financial problems. In addition, further research can add personal factors as new variables, so as to further deepen research studies with this topic.

\section{REFERENCES}

Armstrong, M. B., Ketz, J. E., \&Owsen, D. (2003). Ethics education in accounting: Moving toward ethical motivation and ethical behavior. Journal of accounting education, 21(1), 1-16.

Bampton, R., \&Maclagan, P. (2005). Why teach ethics to accounting students? A response to the sceptics. Business ethics: A European review, 14(3), 290-300.
Basri, M. Y. (2014). Efek Moderasi Religuisitas dan Gender Terhadap Hubungan Etika Uang (Money Ethics) dan Kecurangan Pajak (Tax Evasion). Simposium Nasional Akuntansi XVII. Mataram: Universitas Mataram, 24-27.

Bloodgood, J. M., Turnley, W. H., \&Mudrack, P. (2008). The influence of ethics instruction, religiosity, and intelligence on cheating behavior. Journal of business ethics, 82(3), 557-571.

Burks, B. D., \&Sellani, R. J. (2008).Ethics, religiosity, and moral development of business students. Journal of Leadership, Accountability and Ethics, 49.

Burton, J. H., Talpade, S., \& Haynes, J. (2011).Religiosity and test-taking ethics among Business School students. Journal of Academic and Business Ethics, 4, 1.

Grullon, G., Kanatas, G., \& Weston, J. (2009). Religion, ethics, and corporate behavior. Rice University Working Paper.

Hickman, M. S. (2013). Ethical Reasoning of Accounting Students: Does Religiosity Matter?. International Journal of Business and Social Science, 4(6).

Kidwell, J. M., R. E. Stevens and A. L. Bethke: 1987, 'Differences in Ethical Perceptions Between Male andFemale Managers: Myth or Reality', Journal of Business Ethics 6, 489-493

Lau, T. C., Choe, K. L., \& Tan, L. P. (2013).The moderating effect of religiosity in the relationship between money ethics and tax evasion. Asian Social Science, 9(11), 213. 
Lau, T. C. (2010). Towards socially responsible consumption: an evaluation of religiosity and money ethics. International Journal of Trade, Economics and Finance, 1(1), 32.

Maryani, T. dan U. Ludigdo. 2001. "Survei Atas Faktor-faktor yang Mempengaruhi Sikap dan Perilaku Etis Akuntan". TEMA.Vol 2 No 1.Hal.49-62.

McDonald, G. M. and C. K. Pak: 1997, 'Ethical Perceptions of Expatriate and Local Managers in HongKong', Journal of Business Ethics 16, 16051623.

O'Leary, C. (2009). An empirical analysis of the positive impact of ethics on accounting students. Accounting Education: an international journal, 18(4-5), 505-520.

Sukrisno, Agoes. 2012. AUDITING Petunjuk Praktis Pemeriksaan Akuntan oleh Akuntan Publik. Edisi 4 buku 1. Penerbit Salemba Empat. Jagakarsa, Jakarta Selatan 12610

Sulistiyo, H. (2014). Relevansi nilai religius dalam mencegah perilaku disfungsional audit. Jurnal Ekonomi Manajemen Akuntansi, 21(36).

Tang, Thomas Li-Ping. 2002 . "Is the love of money the root of all evil? Or different strokes for different folks: lessons in 12 countries". Paper presented to the International Conference on Business Ethics in the Knowledge Economy. Hong Kong, China.

Tang, T. L. P., \& Liu, H. (2012). Love of money and unethical behavior intention: Does an authentic supervisor's personal integrity and character (ASPIRE) make a difference?.Journal of Business Ethics, 107(3), 295-312.
Tang, T. L. P., \& Chen, Y. J. (2008). Intelligence vs. wisdom: The love of money, Machiavellianism, and unethical behavior across college major and gender. Journal of Business Ethics, 82(1), 1-26.

Tang, T. L. P., \& Chiu, R. K. (2003). Income, money ethic, pay satisfaction, commitment, and unethical behavior: Is the love of money the root of evil for Hong Kong employees?. Journal of business ethics, 46(1), 13-30.

Wankhar, A. Z., \& Diana, N. (2018).Pengaruh Money Ethics Terhadap Tax Evasion Dengan Reliogiousity, Gender, Materialism Sebagai Variabel Moderating (Studi Kasus pada Wajib Pajak Orang Pribadi yang Terdaftar di KPP Pratama Malang Utara). Jurnal Riset Akuntansi, 7(05).

Wong, H. M. (2008). Religiousness, love of money, and ethical attitudes of Malaysian evangelical Christians in business. Journal of business ethics, 81(1), 169-191. 